\title{
PELATIHAN PENINGKATAN KAPASITAS GURU SISWA BERKEBUTUHAN KHUSUS DI SEKOLAH SAYAP IBU BINTARO
}

\author{
Pradita Sibagariang ${ }^{1}$, Gabriella Irena Carissa ${ }^{2}$, Jessica Paramitha ${ }^{3}$, Weny Pandia \\ Sembiring ${ }^{4}$, dan Penny Handayani ${ }^{5}$
}

\author{
${ }^{1}$ Program Studi Magister Profesi Psikologi Pendidikan, UNIKA Atma Jaya Jakarta \\ Email: pradita.201800040004@student.atmajaya.ac.id \\ ${ }^{2}$ Program Studi Magister Profesi Psikologi Pendidikan, UNIKA Atma Jaya Jakarta \\ Email: gabriel.201800040025@student.atmajaya.ac.id \\ ${ }^{3}$ Program Studi Magister Profesi Psikologi Pendidikan, UNIKA Atma Jaya Jakarta \\ Email: jessica.201800040009@student.atmajaya.ac.id \\ ${ }^{4}$ Jurusan Psikologi, UNIKA Atma Jaya Jakarta \\ Email: weny.pandia@atmajaya.ac.id \\ ${ }^{5}$ Jurusan Psikologi, UNIKA Atma Jaya Jakarta \\ Email: penny.handayani@atmajaya.ac.id
}

\begin{abstract}
Teachers have an important role in the running of educational activities in schools, both regular and special schools. The competence of teachers who teach will greatly determine the achievement of the learning goals given in the ongoing curriculum. With the limited human resources in the area of children with special needs, there are times when teachers who teach do not have the minimum competence needed to make teaching and learning activities run smoothly, so learning targets become a challenge. Teachers in special schools should also have special competencies to handle and educate Students with Special Needs (SBK). This study used a mixed-method with a group discussion forum, interviews, and questionnaires to get a deeper picture of the competence of teachers at the Sayap Ibu Bintaro Foundation (YSIB). The results showed that there are internal and external factors that affect the competence of teachers at YSIB. Teacher knowledge and skills in behavior management, recognizing SBK characteristics, and communication with SBK still need further development. This results in the teacher's teaching strategy not optimal in their daily lives. Therefore, a form of intervention is needed to improve teacher competence, especially in behavior management, recognizing SBK characteristics, and communication skills with SBK. The intervention was carried out by training "Special Need Teacher Capacity Building". The results of the intervention show that training can improve teacher competence, especially in the cognitive and affective aspects, while the behavioral aspect is not maximal because the opportunity to practice the results of the training is still limited.
\end{abstract}

Keywords: Capacity building, special education teacher, teachers' competencies.

\begin{abstract}
ABSTRAK
Guru memiliki peran penting dalam berjalannya kegiatan pendidikan di sekolah, baik sekolah reguler maupun sekolah khusus. Kompetensi guru yang mengajar akan menentukan tercapainya tujuan pembelajaran yang diberikan dalam kurikulum yang berjalan. Dengan keterbatasan sumber daya manusia yang tersedia pada area anak berkebutuhan khusus, ada kalanya guru yang mengajar belum memiliki kompetensi minimal yang dibutuhkan guna menunjang kelancaran kegiatan belajar mengajar (KBM), sehingga target pembelajaran menjadi sebuah tantangan tersendiri. Guru yang mengajar di sekolah khusus pun sebaiknya memiliki kompetensi khusus agar siap untuk menangani dan mendidik Siswa Berkebutuhan Khusus (SBK). Penelitian ini menggunakan mixed method dengan forum group discussion, wawancara, dan kuesioner kepada 5 guru dan Kepala Sekolah untuk mendapatkan gambaran yang lebih mendalam terkait dengan kompetensi guru di Yayasan Sayap Ibu Bintaro (YSIB). Hasil penelitian menunjukkan bahwa terdapat faktor internal dan eksternal yang mempengaruhi kompetensi guru di YSIB. Pengetahuan dan keterampilan guru dalam manajemen perilaku, mengenali karakteristik SBK, dan komunikasi dengan SBK masih perlu dikembangkan lebih lanjut. Hal ini berakibat pada strategi mengajar guru belum optimal dalam kesehariannya. Oleh karena itu, diperlukan suatu bentuk intervensi untuk meningkatkan kompetensi guru, terutama dalam manajemen perilaku, mengenal karakteristik SBK, dan keterampilan komunikasi dengan SBK. Intervensi dilakukan dengan pelatihan "Special Need Teacher Capacity Building". Hasil intervensi menunjukkan bahwa pelatihan dapat meningkatkan kompetensi guru, terutama pada aspek kognitif dan afektif, sedangkan pada aspek perilaku belum terlihat maksimal karena kesempatan untuk mempraktekkan hasil pelatihan masih terbatas.
\end{abstract}

Kata Kunci: Capacity building, guru sekolah khusus, kompetensi guru. 


\section{PENDAHULUAN}

Sekolah dengan sistem pendidikan khusus dirancang untuk memfasilitasi peserta didik yang memiliki kesulitan dalam mengikuti pembelajaran dikarenakan adanya perbedaan secara fisik, mental, sosial, dan/atau memiliki potensi kecerdasan dan bakat istimewa. Kelompok peserta didik tersebut lebih dikenal dengan istilah Siswa Berkebutuhan Khusus (SBK). Adanya kebutuhan khusus menyebabkan SBK membutuhkan pendidikan dan layanan khusus sehingga potensi mereka dapat lebih optimal dan berkembang. Hal ini sejalan dengan Peraturan Pemerintah Republik Indonesia Nomor 72 tahun 1991 tentang Pendidikan Luar Biasa yang menyatakan bahwa sekolah khusus bertujuan untuk membantu SBK dalam mengembangkan sikap, pengetahuan, dan keterampilan sehingga tercipta hubungan timbal-balik dengan lingkungan serta mengembangkan kemampuannya ke dalam dunia kerja atau pendidikan lanjutan (Septiana, 2017).

Sekolah Yayasan Sayap Ibu Bintaro (YSIB) adalah salah satu sekolah pendidikan khusus yang merupakan pengembangan dari panti asuhan YSIB. Sekolah ini memiliki tujuan yang serupa dengan tujuan yang dituliskan dalam peraturan pemerintah. Sekolah YSIB bertujuan untuk mengaktualisasi potensi seluruh peserta didik di dalam seluruh aspek, yakni aspek kognitif, psikososial, emosional, estetika, dan fisik.

Guru berperan penting untuk mencapai visi, misi, dan tujuan dari sekolah YSIB. Guru juga merupakan kunci keberhasilan penyelenggaraan pendidikan. Berdasarkan pentingnya peran guru tersebut, maka guru-guru di sekolah YSIB diharapkan dan diwajibkan untuk memiliki kompetensi yang tinggi dan berkualitas. Secara umum, seluruh guru wajib memiliki kompetensi pedagogik, sikap, profesional, dan sosial sebagaimana yang tertulis di dalam Undang-Undang Nomor 14 tahun 2005 pasal 10 tentang Guru dan Dosen.

Peraturan Pemerintah nomor 19 tahun 2005 tentang standar nasional pendidikan mendefinisikan pengertian masing-masing kompetensi. Kompetensi pedagogik merupakan kemampuan pendidik dalam mengelola pembelajaran peserta didik. Kompetensi kepribadian adalah kemampuan pendidik dalam hal kepribadian, seperti berkepribadian yang mantap, stabil, dewasa, arif, berwibawa, dapat menjadi teladan bagi peserta didik, serta berakhlak mulia. Kompetensi profesional adalah kemampuan pendidik terkait penguasaan materi pembelajaran secara luas dan mendalam sehingga pendidik mampu membimbing peserta didik untuk memenuhi standar kompetensi yang ditetapkan dalam standar nasional pendidikan. Terakhir, kompetensi sosial adalah kemampuan pendidik sebagai bagian dari masyarakat untuk berkomunikasi dan berinteraksi secara efektif dengan peserta didik, sesama pendidik, tenaga kependidikan, orangtua atau wali, dan masyarakat. Keempat kompetensi tersebut saling berkorelasi secara signifikan (Lestari \& Purwanti, 2018). Hal ini berarti setiap kompetensi saling melengkapi sehingga kompetensi guru menjadi utuh dan berkualitas. Selanjutnya, Lestari dan Purwanti (2018) juga menjelaskan bahwa kompetensi pedagogik berkorelasi signifikan dengan ketiga kompetensi lainnya.

Para guru di sekolah pendidikan khusus juga diharapkan memiliki kompetensi khusus dikarenakan guru-guru tersebut berinteraksi dengan SBK. Kompetensi khusus yang diharapkan, antara lain; (1) memahami visi dan misi pendidikan inklusi, (2) memahami karakteristik peserta didik, (3) melakukan asesmen dan evaluasi proses pembelajaran, (4) memahami dan menguasai materi pembelajaran, (5) terampil dan memahami perencanaan dan pengelolaan pembelajaran, (6) terampil dan memahami pengelolaan perilaku dan interaksi peserta didik, dan (7) berkolaborasi dengan mitra di dunia pendidikan (UNESCO, 2004 dalam Ariastuti \& Herawati, 2016). Idealnya, para guru memiliki berbagai kompetensi tersebut agar lebih siap dalam menangani dan mendidik 
SBK sehingga target pendidikan tercapai. Akan tetapi, ketersediaan tenaga kerja guru di lapangan dan sesuai dengan spesifikasi yang diarahkan oleh pemerintah kurang seimbang dengan permintaan sekolah. Hal ini dialami oleh banyak sekolah khusus, termasuk di sekolah YSIB. Guruguru di sekolah YSIB kerap mengalami hambatan dalam pencapaian target pembelajaran pada evaluasi akhir semester.

Berdasarkan pemaparan terkait latar belakang pendidikan guru, pengalaman mengajar, serta kurang tercapainya target pembelajaran peserta didik, maka muncul dugaan adanya kesenjangan antara standar kompetensi guru yang diwajibkan dan kompetensi yang dimiliki oleh guru YSIB. Hingga saat ini, belum terdapat pemeriksaan yang berfungsi untuk mengidentifikasi kompetensi yang dimiliki oleh guru di sekolah YSIB serta kebutuhan para guru tersebut. Hal tersebut berdampak terhadap belum diterapkannya intervensi yang tepat dan efektif sebagai upaya untuk mengatasi kesenjangan yang muncul. Mengingat vitalnya kompetensi guru dalam keseluruhan proses pendidikan, maka pemeriksaan ini dilaksanakan dengan tujuan untuk mengidentifikasi kompetensi yang telah dimiliki oleh para guru di sekolah YSIB sehingga dapat diciptakan intervensi yang efektif untuk meningkatkan kompetensi guru. Kompetensi guru dapat ditingkatkan melalui pelatihan peningkatan kapasitas. Melalui pelatihan, guru dapat dibekali dengan pengetahuan dan keterampilan yang relevan sehingga dapat diterapkan dalam pembelajaran di kelas. Pada saat guru memiliki kompetensi umum dan khusus yang diharapkan, maka akan tercipta lingkungan belajar yang positif bagi peserta didik dan pembelajaran peserta didik dapat berhasil.

\section{METODE PELAKSANAAN PKM Pengambilan data}

Pengambilan data menggunakan mixed method untuk mendapatkan gambaran yang mendalam terkait kompetensi para guru di sekolah YSIB. Mixed method juga dilakukan dengan mempertimbangkan ketersediaan waktu dan fasilitas dari para guru yang bekerja dari rumah dikarenakan kondisi pandemi Covid-19 saat pemeriksaan berlangsung. Metode kualitatif yang digunakan adalah wawancara dan Focus Group Discussion (FGD). Sementara metode kuantitatif yang digunakan adalah kuesioner. Gambaran keseluruhan prosedur pengambilan data dapat dilihat pada Tabel 1.

Proses wawancara dilaksanakan secara individual dan kelompok dengan menggunakan panduan wawancara yang bersifat semi terstruktur. Wawancara individual dilaksanakan kepada kepala sekolah, sementara wawancara kelompok dilakukan kepada lima guru di sekolah YSIB. Tujuan wawancara untuk mendapatkan informasi terkait permasalahan utama yang dirasakan oleh guru serta kompetensi para guru.

Pelaksanaan FGD bertujuan untuk memperoleh pandangan guru di YSIB terhadap kondisi tidak tercapainya target pembelajaran peserta didik. FGD juga dilaksanakan untuk melihat interaksi antar guru. Metode FGD dilaksanakan secara online melalui aplikasi whatsapp video call bersama lima guru YSIB.

Lima guru di sekolah YSIB mengisi kuesioner yang dikembangkan berdasarkan Permendiknas No. 16 tahun 2007 tentang standar kualifikasi dan kompetensi guru dan berdasarkan studi pustaka terkait kompetensi spesifik yang wajib dimiliki oleh guru yang mendidik SBK. Pengisian kuesioner dilakukan secara online melalui google form. Kuesioner berupa pernyataan dengan skala Likert dan pertanyaan. Guru menentukan kesesuaian antara pernyataan yang ada dengan kompetensi yang mereka miliki saat pemeriksaan dilaksanakan. Tujuannya adalah untuk mengidentifikasi kompetensi yang telah dimiliki serta kompetensi yang perlu dikembangkan oleh guru-guru YSIB. 
Tabel 1. Gambaran Keseluruhan Prosedur Pengambilan Data

\begin{tabular}{cccc}
\hline Metode Asesmen & Sumber & Jumlah Peserta & Keterangan \\
\hline \multirow{2}{*}{ Wawancara } & Kepala sekolah & 1 orang & Tanggal 7 dan 13 April 2020 \\
\cline { 2 - 4 } & Guru & 5 orang & Tanggal 14, 15, dan 30 April 2020 \\
\hline FGD & Guru & 5 orang & Tanggal 9 April 2020 \\
\hline Kuesioner & Guru & 5 orang & Tanggal 15 dan 23 April 2020 \\
\hline
\end{tabular}

\section{Analisa Data}

Metode analisis untuk mengidentifikasi akar permasalahan yang dirasakan oleh para guru di sekolah YSIB menggunakan pemetaan pohon masalah. Pencarian akar masalah dilaksanakan dengan menentukan sebab dan akibat dari permasalahan berdasarkan penggabungan hasil FGD dan hasil kuesioner. Bagan pohon masalah dapat dilihat pada Gambar 1.

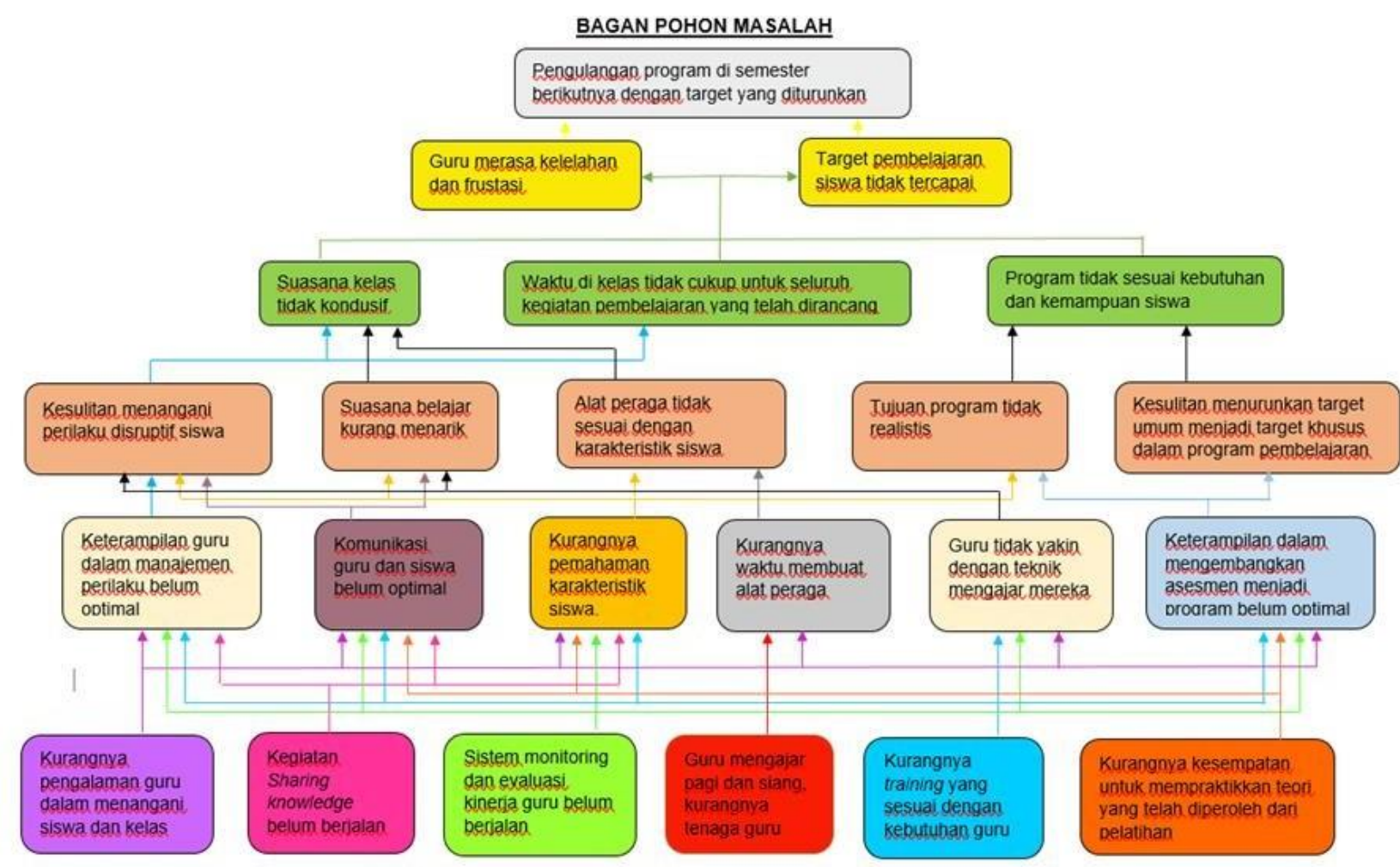

Gambar 1. Pohon Masalah

Berdasarkan pohon masalah, terlihat beberapa masalah yang dialami oleh para guru di sekolah YSIB. Masalah tersebut diutarakan dalam kotak berwarna orange muda pada bagan pohon masalah. Berbagai masalah ini menyebabkan munculnya kondisi yang dipetakan pada kotak berwarna hijau dan kuning dalam bagan pohon masalah.

Berbagai permasalahan yang muncul disebabkan oleh faktor internal (faktor di dalam diri guru) dan faktor eksternal (faktor di luar diri guru). Guru merasa bahwa faktor eksternal mempengaruhi faktor internal dan turut mendukung munculnya permasalahan. Penyebab yang termasuk faktor internal, antara lain belum optimalnya keterampilan guru dalam manajemen perilaku, komunikasi guru dan peserta didik belum optimal, belum memadainya pemahaman guru terkait karakteristik peserta didik, kurangnya waktu untuk membuat alat peraga, guru belum yakin dengan teknik mengajar, serta belum optimalnya keterampilan dalam mengembangkan asesmen menjadi program pembelajaran. Pada umumnya, berbagai penyebab tersebut merupakan aspek-aspek dari kompetensi pedagogik yang wajib dimiliki oleh guru. Selanjutnya, penyebab eksternal antara lain 
kurangnya pengalaman dalam menangani peserta didik, kegiatan sharing knowledge belum berjalan, sistem monitoring dan evaluasi kinerja guru yang belum konsisten, tanggung jawab guru untuk mengajar di dua kelas, kurangnya jumlah guru, kurangnya pelatihan yang sesuai kebutuhan guru, serta kurangnya kesempatan untuk mempraktikkan teori yang diperoleh dari pelatihan.

Setelah merumuskan hubungan sebab dan akibat dalam pohon masalah, para guru YSIB menyatakan bahwa masalah yang paling penting untuk diatasi berupa peningkatan kompetensi pedagogik, terutama berkaitan dengan manajemen perilaku peserta didik, pengenalan karakteristik SBK, serta keterampilan komunikasi dengan SBK. Para guru di sekolah YSIB menyatakan bahwa keterampilan mereka dalam manajemen perilaku dan keterampilan komunikasi dengan SBK belum optimal. Guru juga mengakui bahwa pemahaman mereka terkait karakteristik peserta didik masih terbatas. Sejauh ini, para guru belum mendapatkan intervensi yang efektif terkait ketiga hal tersebut sehingga guru belum memahami secara maksimal tentang karakteristik peserta didik, strategi manajemen perilaku yang tepat, serta prosedur asesmen keterampilan komunikasi bagi peserta didik. Tingkat keterampilan guru yang cenderung sama menyebabkan para guru kesulitan menyelesaikan masalah ini dengan berdiskusi, seperti yang selama ini mereka lakukan ketika menemui hambatan.

Setelah guru memperoleh akar penyebab permasalahan dan menyepakati permasalahan yang paling penting untuk diselesaikan, maka peneliti bersama para guru mulai mengembangkan pohon tujuan. Pohon tujuan yang dikembangkan dapat dilihat pada Gambar 2.

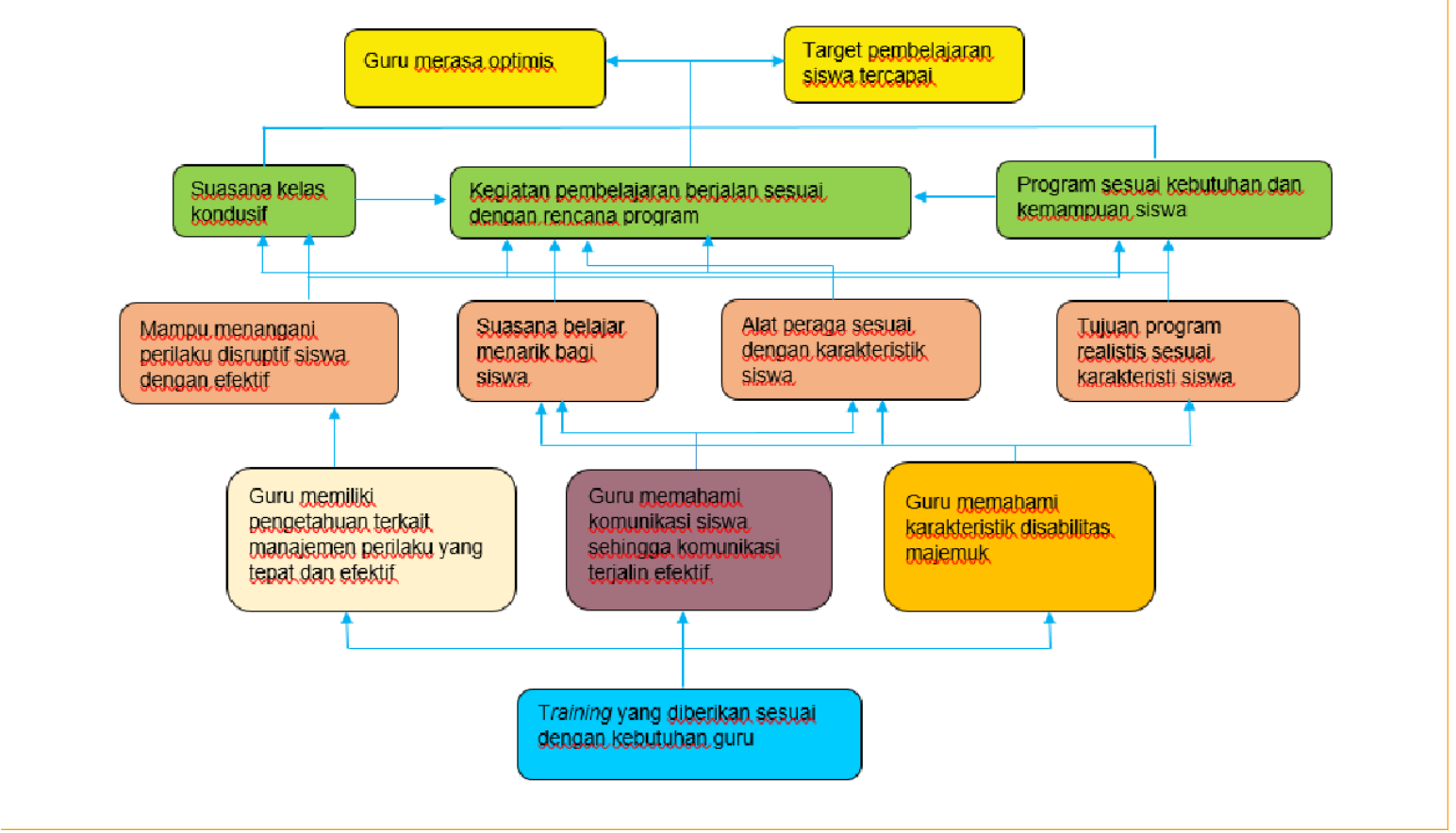

Gambar 2. Pohon Tujuan

\section{Rancangan Intervensi}

Berdasarkan keseluruhan hasil analisa, maka dilaksanakan asesmen lanjutan untuk mengetahui pemahaman para guru terkait karakteristik peserta didik, manajemen perilaku, serta komunikasi. Hasil asesmen digunakan sebagai dasar pengembangan tujuan dan program intervensi sehingga efektif dan sesuai kebutuhan.

Berdasarkan keseluruhan hasil asesmen kebutuhan, didapati bahwa pengetahuan serta pemahaman 
guru masih terbatas terkait karakteristik peserta didik, strategi manajemen perilaku disruptif peserta didik, serta keterampilan dalam berkomunikasi dengan SBK. Hal ini menyebabkan strategi-strategi yang dikembangkan oleh guru belum efektif, optimal, dan sesuai dengan karakteristik peserta didik. Oleh karena itu, peneliti memberikan intervensi berupa pelatihan peningkatan kapasitas bagi guru di sekolah YSIB. Sebelum mengikuti pelatihan, para peserta diberi kesempatan untuk membaca materi pelatihan dalam bentuk booklet yang dikirimkan peneliti lima hari sebelum pelatihan dilaksanakan.

Pelatihan diberikan melalui video teleconferencing dengan aplikasi zoom dikarenakan situasi Pembatasan Sosial Berskala Besar (PSBB) yang tidak memungkinkan untuk mengadakan pelatihan secara langsung. Video teleconferencing dikategorikan sebagai pembelajaran jarak jauh (distance learning), yakni pembelajaran yang terpisah tempat dan waktu antara pelatih dan peserta, serta interaksi antar peserta dilakukan melalui satu atau lebih media. Pelatihan dengan distance learning merupakan alternatif yang paling mungkin dapat dilakukan dalam situasi PSBB. Pelatihan terbagi ke dalam tiga topik; karakteristik disabilitas, strategi manajemen perilaku, dan keterampilan komunikasi dengan SBK. Gambaran pelatihan dapat dilihat pada Tabel 2.

Tabel 2. Gambaran Pelatihan

\begin{tabular}{|c|c|c|c|}
\hline Pelaksanaan & Tujuan Umum & Tujuan Khusus & Jumlah Peserta \\
\hline $\begin{array}{l}\text { Kamis, } \\
14 \text { Mei } 2020 \text { dan } \\
\text { Jumat, } 15 \text { Mei }\end{array}$ & $\begin{array}{l}\text { Guru sekolah YSIB } \\
\text { memahami strategi } \\
\text { manajemen perilaku. }\end{array}$ & $\begin{array}{l}\text { Guru mampu memahami definisi perilaku } \\
\text { disruptif serta hubungannya dengan manajemen } \\
\text { perilaku }\end{array}$ & $\begin{array}{l}1 \text { kepala sekolah } \\
\text { dan } 5 \text { guru. }\end{array}$ \\
\hline
\end{tabular}

2020.

pk $10.00-12.00$
Guru mampu mengidentifikasi penyebab, konsekuensi, dan fungsi dari masalah perilaku siswa.

Guru mampu mengembangkan strategi manajemen perilaku yang efektif.

Guru mampu memahami teknik monitoring dan evaluasi terhadap manajemen perilaku yang diterapkan.

\begin{tabular}{|c|c|c|c|}
\hline \multirow{4}{*}{$\begin{array}{l}\text { Selasa, } 2 \text { Juni } \\
2020 \\
\text { pk 10.30-12.30 }\end{array}$} & \multirow{4}{*}{$\begin{array}{l}\text { Guru memahami } \\
\text { karakteristik disabilitas } \\
\text { (Autism Spectrum } \\
\text { Disorder, Intellectual } \\
\text { Disability, Physical } \\
\text { Disability, dan Multiple } \\
\text { Disability) }\end{array}$} & Guru memahami definisi disabilitas & \multirow{4}{*}{$\begin{array}{l}1 \text { kepala sekolah } \\
\text {-dan } 5 \text { guru. }\end{array}$} \\
\hline & & Guru memahami ciri utama disabilitas & \\
\hline & & Guru memahami penyebab disabilitas & \\
\hline & & Guru memahami penanganan pada SBK & \\
\hline \multirow{5}{*}{$\begin{array}{l}\text { Rabu, } 3 \text { Juni } 2020 \\
\text { pk } 10.30-13.00\end{array}$} & \multirow{5}{*}{$\begin{array}{l}\text { Guru mengembangkan } \\
\text { pengetahuan serta } \\
\text { keterampilan komunikasi } \\
\text { dengan siswa } \\
\text { berkebutuhan khusus } \\
\text { majemuk. }\end{array}$} & $\begin{array}{l}\text { Guru mampu memahami konsep teori } \\
\text { komunikasi. }\end{array}$ & \multirow[t]{5}{*}{$\begin{array}{l}1 \text { kepala sekolah } \\
\text { dan } 4 \text { guru. }\end{array}$} \\
\hline & & Guru mengetahui alat asesmen komunikasi. & \\
\hline & & Guru sadar pentingnya komunikasi. & \\
\hline & & $\begin{array}{l}\text { Guru sadar pentingnya asesmen komunikasi bagi } \\
\text { siswa berkebutuhan khusus majemuk. }\end{array}$ & \\
\hline & & $\begin{array}{l}\text { Mengaplikasikan teori ke dalam aktivitas } \\
\text { mengajar. }\end{array}$ & \\
\hline
\end{tabular}




\section{HASIL DAN PEMBAHASAN}

\section{Hasil dan evaluasi pemberian booklet}

Pemberian booklet terbukti berhasil membantu para guru dalam mempersiapkan diri untuk mengikuti pelatihan, baik dari segi pertanyaan ataupun pemahaman. Pemberian booklet juga meningkatkan pengetahuan guru mengenai keseluruhan materi pelatihan. Hal ini terlihat dari pertanyaan guru yang lebih berfokus kepada pemahaman, aplikasi, dan analisis materi saat pelatihan berlangsung.

\section{Hasil dan evaluasi pelatihan pemahaman karakteristik disabilitas}

Evaluasi pelatihan menggunakan pre test dan post test untuk mengetahui tingkat pemahaman guru terhadap karakteristik disabilitas. Nilai diberikan dengan cara menghitung jumlah jawaban benar (x10) sehingga nilai maksimal adalah 100. Dilihat dari hasil tes, tingkat pemahaman guru mengalami kenaikan. Rata-rata nilai yang dicapai guru pada pre-test 52.5 dan post-test 77.5, sehingga disimpulkan terdapat peningkatan 25 point pada peserta. Sasaran peneliti adalah pemahaman guru terhadap karakteristik disabilitas SBK. Oleh karena itu, peneliti memberikan tugas individu yaitu memetakan karakteristik disabilitas salah satu SBK di kelas. Melalui tugas tersebut peneliti melihat proses guru dalam mengklasifikasikan dan menjelaskan materi karakteristik disabilitas dengan konteks SBK yang diajar. Tugas individu guru dinilai secara kualitatif. Secara umum, guru-guru mampu menyebutkan karakteristik SBK, kelebihan dan aspek yang perlu ditingkatkan dari SBK, serta menentukan faktor pendukung atau penghambat dalam pembelajaran SBK. Guru mengerjakan dalam bentuk bagan dan mengumpulkan melalui aplikasi Whatsapp. Peneliti membantu guru untuk memastikan kembali kondisi SBK yang dituliskan di dalam bagan. Hal ini dilakukan agar guru dapat mengetahui hal yang sudah tepat dan yang masih perlu disesuaikan. Evaluasi pelaksanaan berdasarkan durasi waktu pelatihan, manfaat materi, dan metode penyampaian. Secara keseluruhan, pelatihan bermanfaat dan sesuai kebutuhan guru. Materi yang diberikan telah rinci dan disertai contoh kasus dan praktek pemetaan karakteristik. Hal yang perlu ditingkatkan yaitu penyampaian materi dari segi tampilan presentasi dan penjelasan contoh kasus.

\section{Hasil dan evaluasi pelatihan manajemen perilaku}

Evaluasi pelatihan dibagi ke dalam tiga bagian; evaluasi kegiatan umum pelatihan, evaluasi tujuan khusus, dan evaluasi latihan. Evaluasi dilakukan berdasarkan pemantauan selama kegiatan pelatihan serta analisa kuesioner yang diisi oleh peserta.

Evaluasi kegiatan umum dilihat dari segi waktu, pemilihan materi, dan respon peserta, sbb:

1. Pada aspek waktu, kegiatan pelatihan berjalan sesuai rencana.

2. Pada aspek pemilihan materi, seluruh guru menyatakan bahwa materi yang diberikan bermanfaat. Pemilihan materi dirancang berdasarkan kebutuhan para guru dan disesuaikan dengan tujuan pelatihan.

3. Pada aspek respon peserta, para guru menunjukkan antusiasme dengan aktif berpendapat saat diskusi berlangsung, menyampaikan pertanyaan aplikatif terkait materi, begitu pula dengan insights yang didapat selama pelatihan. Hal ini didukung dengan hasil kuesioner yang menyatakan bahwa para guru merasa tertarik, bahagia, dan antusias selama pelatihan dikarenakan pelatihan sesuai dengan harapan mereka. Para guru menyatakan bahwa pelatihan yang diberikan mampu menambah ilmu, wawasan, serta keterampilan mereka dalam manajemen perilaku.

Selanjutnya evaluasi pencapaian tujuan khusus berdasarkan kognitif, afektif, dan perilaku.

1. Secara kognitif, seluruh guru menyatakan bahwa pelatihan membantu mereka dalam 
memahami definisi perilaku disruptif, faktor pembentuk perilaku, definisi manajemen perilaku, serta pelaksanaan manajemen perilaku. Seluruh guru juga menyatakan bahwa setelah mengikuti pelatihan, pemahaman terkait langkah-langkah asesmen perilaku, jenis strategi manajemen perilaku serta pengaplikasiannya, serta langkah-langkah dalam monitoring dan evaluasi manajemen perilaku menjadi meningkat. Peningkatan kognitif merupakan hal penting sebelum akhirnya guru mampu menerapkan manajemen perilaku yang efektif di kelas. Pada saat guru memiliki pengetahuan yang luas tentang manajemen perilaku maka guru tersebut semakin sering menerapkan strategi manajemen perilaku dan strategi yang dikembangkan semakin tepat dan efektif (Moore, Wehby, Oliver., dll, 2017). Peningkatan pengetahuan dan pemahaman guru tentang manajemen perilaku dapat membantu mereka dalam menerapkan strategi manajemen perilaku yang efektf saat pembelajaran. Jika penerapan strategi manajemen perilaku berlangsung efektif, maka perilaku positif peserta didik serta keberhasilan target pembelajaran semakin meningkat, dan tingkat frustasi guru menurun (Kuriyan, 2015).

2. Secara afektif, para guru antusias dalam mendengarkan penjelasan materi, berdiskusi, dan menganalisis kasus. Berdasarkan hasil kuesioner, guru menyatakan bahwa mereka merasa tertarik dan antusias selama pelaksanaan pelatihan.

3. Secara perilaku, guru mampu menentukan strategi manajemen perilaku berdasarkan hasil asesmen dan mengembangkan strategi anteseden, perilaku, dan konsekuensi yang selaras. Hal ini disebabkan adanya latihan yang memberikan gambaran mengenai pelaksanaan asesmen perilaku serta pengembangan strategi manajemen perilaku. Akan tetapi, guru belum berkesempatan untuk mengaplikasikan secara langsung strategi manajemen perilaku dikarenakan pandemi Covid-19.

Evaluasi terakhir dilakukan terhadap latihan kasus. Tujuan dari berbagai latihan telah tercapai. Guru-guru telah memahami keseluruhan rangkaian asesmen perilaku. Hal ini terlihat dari ketepatan jawaban yang meningkat pada latihan.

\section{Hasil dan evaluasi pelatihan keterampilan komunikasi guru dengan SBK}

Terdapat dua bagian evaluasi, yaitu evaluasi kegiatan umum dan evaluasi tujuan pelatihan. Evaluasi umum dilakukan dengan observasi selama pelatihan dan kuesioner. Sedangkan evaluasi tujuan dilakukan membandingkan hasil pre-test dengan post-test dan observasi selama pelatihan. Evaluasi kegiatan umum dilihat dari lima aspek:

1. Waktu pelaksanaan. Pelatihan dimulai dan selesai terlambat 10-15 menit dari jadwal yang direncanakan. Keterlambatan ini berkaitan dengan aspek teknis, yang mana dua peserta kesulitan masuk ke ruang pelatihan online karena koneksi internet. Namun, hasil kuesioner menyatakan bahwa waktu pelatihan masih sesuai dengan rencana pelatihan.

2. Jumlah peserta pelatihan. Hanya empat guru dan satu orang kepala sekolah. Satu guru berhalangan hadir karena membantu guru lain yang sedang menjaga di sekolah.

3. Pemilihan materi. Berdasarkan hasil kuesioner, para guru menyatakan bahwa materi keterampilan mengenali komunikasi SBK dengan lembar-lembar asesmen sangat membantu dan tepat dengan kebutuhan mereka. Sedangkan materi terkait pengetahuan dasar komunikasi dan komunikasi pada SBK membantu memenuhi kebutuhan mereka sebagai guru. Seluruh peserta setuju bahwa materi pelatihan sesuai dengan harapan dan bermanfaat bagi mereka dalam menjalankan tugas sebagai guru.

4. Respon peserta selama sesi pelatihan dirasa aktif dan kooperatif.

5. Fasilitator. Berdasarkan hasil kuesioner, seluruh guru setuju bahwa fasilitator menguasai materi, mampu menyampaikan materi dengan jelas, dan mampu untuk melibatkan peserta untuk berperan aktif selama sesi pelatihan. 
Evaluasi tujuan pelatihan dilihat dari pencapaian tujuan kognitif, afektif, dan perilaku:

1. Evaluasi kognitif dilihat dari perbandingan hasil pre-test dengan post-test. Rata-rata pre-test adalah 3,75 dan rata-rata post-test adalah 7,67. Artinya, pengetahuan peserta meningkat setelah mengikuti pelatihan.

2. Evaluasi tujuan afektif didapatkan dari hasil observasi selama pelatihan. Peserta menyadari pentingnya komunikasi dan keterampilan untuk menggunakan lembar asesmen dalam mengenali komunikasi SBK. Hal ini terlihat dari sikap kooperatif dan aktif selama pelatihan.

3. Evaluasi tujuan perilaku dilihat dari kemampuan peserta dalam menggunakan lembar asesmen. Keadaan pandemi Covid-19 membatasi guru untuk berinteraksi dengan SBK, sehingga evaluasi tujuan perilaku hanya dapat dilihat dari latihan selama pelatihan. Dalam proses latihan, terdapat peserta yang kesulitan dalam mengisi. Namun, peserta aktif bertanya dan menjawab hingga akhirnya seluruh peserta mampu mengisi lembar asesmen dengan tepat.

\section{KESIMPULAN DAN SARAN}

Keseluruhan evaluasi pelatihan menunjukkan bahwa tujuan umum pelaksanaan pelatihan peningkatan kapasitas pada guru SBK di sekolah YSIB telah tercapai dari segi kognitif dan afektif. Para guru sekolah YSIB telah memiliki pengetahuan dan pemahaman dalam hal manajemen perilaku, karakteristik disabilitas, dan keterampilan komunikasi dengan SBK. Akan tetapi, tujuan umum pelaksanaan pelatihan belum tercapai secara maksimal dari segi perilaku. Para guru sekolah YSIB telah memiliki keterampilan dalam mengembangkan asesmen komunikasi, asesmen perilaku, serta strategi manajemen perilaku pada berbagai latihan kasus yang diberikan. Akan tetapi, para guru belum berkesempatan untuk menerapkan strategi manajemen perilaku yang dirancang serta melakukan asesmen terhadap peserta didik dari segi karakteristik dan komunikasi. Hal ini dikarenakan situasi Covid-19 yang menyebabkan pembelajaran di sekolah tidak berlangsung.

Peneliti merasa terdapat rekomendasi yang dapat dilakukan pihak sekolah YSIB untuk menunjang hasil intervensi, antara lain:

1. Memberikan pelatihan berkala mengenai ketiga topik pelatihan ini mengingat ketiga topik tersebut merupakan topik dasar yang sangat penting. Selain bertujuan untuk mempertahankan pengetahuan para guru mengenai ketiga topik tersebut, pelatihan berkala dapat menajamkan keterampilan guru dalam menerapkan materi-materi tersebut. Topik pelatihan berkala dapat disesuaikan dengan kebutuhan guru dan perlu dievaluasi sehingga pelatihan berikutnya dapat lebih berkembang.

2. Kepala sekolah sebaiknya memonitor dan mengevaluasi kinerja guru dalam memahami peserta didik, melaksanakan manajemen perilaku dan berkomunikasi dengan SBK. Hal ini penting agar guru memiliki panduan dalam melaksanakan tugasnya. Selain itu, monitoring dan evaluasi dapat pula berguna untuk mengukur dampak pelatihan yang telah diberikan sebelumnya terhadap aspek perilaku para guru, mengingat aspek perilaku belum dapat terukur dikarenakan kondisi pandemi.

3. Perlu diadakan pertemuan rutin agar guru dan kepala sekolah dapat bertukar pikiran dan berdiskusi mengenai kebutuhan atau kesulitan yang dihadapi guru saat menerapkan manajemen perilaku dan berkomunikasi dengan SBK.

Selanjutnya, terdapat rekomendasi yang dapat diterapkan penelitian selanjutnya, seperti:

1. Memastikan ketersediaan waktu peserta pelatihan, sehingga jarak antara satu pelatihan dengan pelatihan lainnya tidak terlalu jauh dan pelatihan dapat menjadi satu rangkaian yang 
lebih utuh.

2. Menyediakan metode lain untuk mengevaluasi pelatihan dari segi perilaku.

Ucapan Terima Kasih (Acknowledgement)

Tim mengucapkan terimakasih yang sebesar-besarnya atas bantuan semua pihak yang telah mendukung dalam mewujudkan tercapainya pelatihan "Special Needs Teacher Capacity Building pada Yayasan Pendidikan Sayap Ibu Bintaro". Dukungan diberikan dalam bentuk pemberian informasi berupa data dan waktu luang untuk melaksanakan pelatihan ini. Yayasan pendidikan Sayap Ibu Bintaro yang telah menerima tim dengan tangan terbuka, khususnya Ibu Tuti Hendrawati, selalu Manager Yayasan Pendidikan dan Bapak Agus Triharyanto, S.Pd; selaku Kepala Sekolah. Terimakasih juga diberikan kepada Magister Profesi Psikologi Pendidikan UNIKA Atma Jaya yang telah memberikan dukungan moril sehingga kegiatan ini dapat berjalan dan selesai.

\section{REFERENSI}

Ariastuti, R., \& Herawati, V. (2016). Optimalisasi peran sekolah inklusi. Jurnal Pengabdian pada Masyarakat, 1(1), 38-47.

Kuriyan, A. (2015). The effectiveness of an online workshop on behavior management as a professional development tool for teachers (Electronic Theses and Dissertation). Florida International University: Florida.

Lestari, Y. A., \& Purwanti, M. (2018). Hubungan kompetensi pedagogik, profesional, sosial, dan kepribadian pada guru sekolah dasar nonformal X. Jurnal Pendidikan, 2(1), 199.

Moore, T. C., Wehby, J. H., Oliver, R. M., Chow, J. C., Gordon, J. R., \& Mahany, L. A. (2017). Teachers' reported knowledge and implementation of research-based classroom and behavior management strategies. Remedial and Special Education, 38(4), 222-232.

Pemerintah Indonesia. (2005). Peraturan Pemerintah Republik Indonesia Nomor 19 Tahun 2005 tentang Standar Nasional Pendidikan. Lembaran RI tahun 2005 No. 41. Jakarta: Sekretariat Negara.

Pemerintah Indonesia. (2005). Undang-Undang Republik Indonesia Nomor 14 Tahun 2005 tentang Guru dan Dosen. Lembaran RI tahun 2005 No. 157. Jakarta: Sekretariat Negara.

Poznanski, B., Hart, K., \& Cramer, E. (2018). Are Teachers Ready? Preservice Teacher Knowledge of Classroom Management and ADHD. School Mental Health, 10(3), 301313. https://doi.org/10.1007/s12310-018-9259-2.

Septiana, F. I. (2017). Peran guru dalam standar proses pendidikan khusus pada lingkup pendidikan formal (sekolah luar biasa/ sekolah khusus). Journal of Special Education, 3(2). https://doi.org/10.30999/jse.v3i2.14. 